\title{
MEASURING THE REVISIT INTENTION USING CITY BRANDING CONCEPT
}

\author{
Ubjaan Jusak*, Nimran Umar, Suharyono, Kusumawati Andriani \\ Doctoral Program of Administrative Science, Faculty of Administrative Science, \\ University of Brawijaya, Indonesia \\ *E-mail: humas@ub.ac.id
}

\begin{abstract}
The main purpose of this study was to build an understanding of the impact of city branding concept implementation on revisit intention with mediating variable of tourist satisfaction. In the tourism sector, recurring behavioral intentions are condition that describes the consumer's plan to revisit previously visited tourist destinations. The understanding of satisfaction and intention to return is very important because it is useful to develop tourism products that exist in the city especially related to aspects of city branding. This type of research was explanatory. The samples used in this study were 142 domestic tourists in the city of Ambon, Indonesia. Ambon Island has a characteristic surrounded by a group of islands that offer many natural attractions, beaches, recreation places, historical places and cultural heritage. General Structure of Component Analysis used to analyze the relationship between city branding concepts, satisfaction and revisit intention. The findings showed that city branding has a significant influence towards satisfaction of tourists and revisit intention. Besides, the satisfaction of tourists had a significant influence towards revisit intention.
\end{abstract}

\section{KEY WORDS}

City branding, satisfaction, revisit intention, tourist, tourism sector, tourist satisfaction

One of the most recent and strategic forms of tourism destination branding is the implementation of city branding which is the agenda of many municipalities in introducing the character of the city in the tourism market. City branding is a marketing concept with a brandlike approach that makes the cities as same as commercial goods. In other words, the brand tries to give a different identity to a city so that it can differentiate with competitors. In addition, increased competition among cities has led to increasing the use of marketing strategies. City marketing strategy using city branding approach became border phenomenon in around the world (Kavaratzis and Ashworth, 2004). The city branding concept is a strategy to brand a city that serves as a tool to introduce or market the city's potentials. In both local and international target markets (Kavaratzis, 2005) As an innovative measurement instrument, city branding makes it easier for city government to know the perception of citizens and visitors about the city (Porpescu and Cobos, 2010). On the other hand, the intense competition in the tourism industry causes the tourists to have important meaning for tourism service companies. It can be an asset that must be maintained in order not to move to a competitor. Chen and Phou (2013) stated that intense competition can be overcome by creating a strategy that can generate potential demand from the public in general and tourists in particular. The power of demand can be predicted how many market opportunities will be available in the future. Steps that can be used to predict tourists are to pay attention to satisfaction and intention to return. The understanding of satisfaction and intention to return is very important because it is useful to develop tourism products that exist in the city especially related to aspects of city branding.

The decision-making process of returning to a tourist destination is synonymous with the decision to buy back a product. The intentions of return visits to a city can be described as a pride of the city's inspiration (Kavaratzis, and Asworth, 2004). One measure of city success can be shown through the level of satisfaction and the intention of tourists to visit again to the same city. Satisfaction with the service or product that has been used is the trigger factor of the establishment of repetitive behavior intention (Bitner et al., 1997). In the tourism sector, recurring behavioral intentions are a condition that describes the consumer's 
plan to revisit previously visited tourist destinations. Re-visiting intentions are considered to be a consequence of the tourist satisfaction model, and there are many people in determining vacations are still highly dependent on the 'revisit intention '(Kemperman et al., 2003, Anwar and Sohail, 2004). Satisfaction is an emotional response to what experienced tourists. Previous research revealed that there is a direct relationship between the satisfaction of tourists and the intention to visit back to the city of Bandung (Pratminingsih et al., 2014). The author also has not found the use of city branding variable and its relation to the satisfaction of tourists in tourism research. Thus, this study is directed to the understanding of brand as a marketing concept that can be used as a measurement instrument in the urban tourism sector, with the main objective is to measure its direct impact on the level of satisfaction and revisit intention.

The implementation of city branding on the city can use the name, the tag line, the symbol or a combination of all of them to attract tourists. Travelers tend to pay attention to the tag line as a tool to know the characteristic of a city (Kusumawati, 2017). Therefore, almost every city today has a tagline as a media message in attracting the attention of the public about the characteristics of the city. The city of Ambon, located in the eastern part of Indonesia, has a nickname of "Ambon Manise" which means having a fertile, beautiful and beautiful nature, being the center of provincial government, and the gate of tourism in Maluku province. The city of Ambon has an appeal as it lies along the coastline following the 'Ambon bay line' against the backdrop of the hills to give a distinctive impression to every visitor (Leirissa et al., 2004). The city government of Ambon in 2012 has launched the city's tagline "Ambon, The City of Music" and together with the Indonesian Creative Economy Agency has launched "Ambon, Towards the City Music of World." This tagline illustrates that since the first Ambonese community has a talent in the field of musical art as an inheritance ancestor such as Tifa, Totobuang (gong-shaped gamelan), Tahuri (Tramshell trumpet), Arababu, Ukulele and bamboo flute. Music becomes one of the economic forces of the future. Therefor, it needs to be preserved. All these historical heritage, culture and local wisdom can be packed for city branding and professionally managed as a tourism development policy of Ambon city. Successful branding is not only limited to communication and marketing but also to the city, business and investment planning (Herget et al, 2015). This combination of all development sectors becomes a competitive force that aims to create satisfaction and encourage repetitive behavior in the future. A number of previous studies reveal that there is a significant relationship between satisfaction and revisit intention and the intention to recommend (Ajzen, 1991; Lin, 2012; Pratminingsih, 2014). Therefore, the purpose of this study is to measure the level of revised intention with city branding as well as to measure the effect of customer satisfaction on revisit intention due to the impact of city branding implementation.

\section{THEORETICAL REVIEW}

The City Branding Concept. In the tourism industry, the brand concept is developed in response to changing status and the role of tourism in the global environment. Brands are able to market a product with a unique look or message will win the competition. A brand strategy approach known as city branding is believed to provide a different identity in every city (Herget et al., 2015). City branding depicts a character, charm, style, and personality of a city. A successful city branding is not only a good form of marketing communication but also reaches city planning, regulation, local wisdom, trade, and investment. Mailanen and Rainisto (2009) state city branding as city management through strategic innovation and economic, commercial, social, cultural, and governmental coordination. City branding is the process of forming a city brand to be known by the target market ie investors, tourist, talent, events and others using icons, taglines, slogans, exhibitions, expo or other promotional media (Anholt, 2006).

The two main issues in the process of comparing the city are (1) city branding acts as a means of broadcasting the identity of a city, (2) city branding is seen as an instrument in the capacity of competition (Herget et al, 2015). In the tourism sector, Anholt (2007) measured 
the world's major cities based on six aspects of "City Branding Hexagon" namely; (1) Presence, covering the city's international status, community knowledge of the city; (2) Place, covering the public perception of the physical aspects of the city, environmental hygiene, climate, iconic buildings, and urban parks; (3) Pre-Requisites, about views of city accommodation, public facilities such as hospitals, schools, transportation, sports facilities and asya; (4) People, including resident friendliness, friendship and security; (5) Pulse; (6) Potential, covering the economic opportunities, jobs, business as well as the higher education facilities available in the city. The figure of six aspects of Brain Hexagon by Anholt as follows:

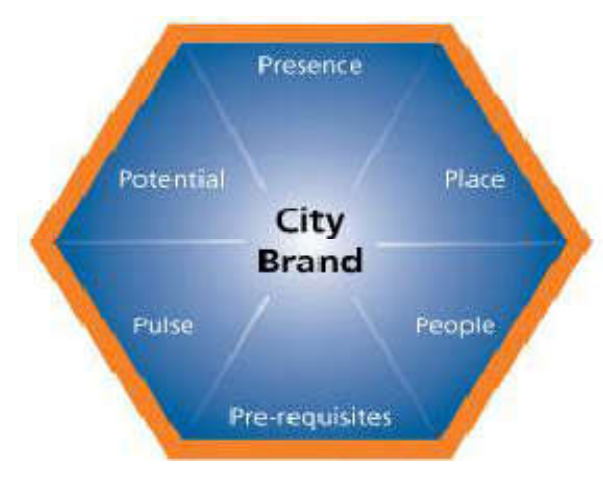

Figure 1 - City Brand Hexagon

As like the positioning of a product, then the city branding is a strategy to strengthen the position of a city to be widely known. City branding can restore the identity of many unknown and neglected cities to compete globally. Acceleration of technology also changed the city from local to global environment and competition to become an attractive tourist destination. The previous research mentioned that the main purpose of city branding is to revitalize investment and tourism with the main target to increase the inflow of tourists to a city (Kavaratzis, 2004).

A city that has a big name will attract many people from different parts of the world to come visit, stay, study, work and enjoy the attractions available on the city (Sjafrizal, 2014). Previous findings suggest that attractive city destinations will generate satisfaction for toris and will further build loyalty (Manhurrun et al., 2014). Customer satisfaction is the target of most companies because it is a predictor of repeat purchase intention. Therefore, tourists as customers of city destinations become assets that must be maintained so it is not easy to move to a competitor.

The Tourists Satisfaction. Consumer satisfaction theory assumes that one's satisfaction is influenced by positive or negative feelings that are associated with buying and consuming goods or a service. When buying a product, the consumer has an expectation of how the product is performing. In the context of tourism services marketing, Payangan (2014) stated that tourism business actors should pay attention to the fulfillment of tourist satisfaction. The customers satisfied will become pioneers or determinants in terms of continuity of a service business. Terms in determining the level of satisfaction are known from the attitude of fun, frequent visits, recommending friends and provide solutions to what is felt in the service tour. The Satisfied of customers will be loyal to the various services offered. Customer satisfaction factor is also an important element in adding customer value as well as value for tourism management companies. Morgan et al (2004) state that in a highly competitive tourism market, the city government and all stakeholders must work hard to showcase the distinctive characteristics of different cities, as well as perform services based on customer satisfaction. This is an important concern because the impression of tourists to a city can turn into negative if that emanated from the city does not meet their expectations (Riza et al, 2012). The size of the quality standard specified by the manufacturer is not necessarily the same as the standard quality measure specified by the consumer. For example, in providing the same service to different tourism customers, the level of satisfaction perceived by each customer 
will be different too. However, business actors continue to give attention to the customer (customer care) with all the power so that the service remains the best in the eyes of consumers. The relationship between variables can be seen in the implementation of city branding in various cities that is a powerful marketing communication tool in building a positive impression and satisfaction for every visitor. The previous research mentioned that the attraction factor of the city, recreational facilities and other attributes of the city can create satisfaction for the visitor causing the intention to return to vacation in the same city (Khuong and Ha., 2014).

The Revisit Intention. Revisit intention refers to the willingness of tourists to revisit the same tourist destinations. Revisit intention is the possibility of tourists to repeat the activity or return to a destination that has been visited before (Lin, 2012). Revisit intention is a future behavioral commitment to buy back products or services or connect with service providers on other occasions (Chen and Chen, 2010). The company's fundamental reason for maintaining and improving tourists visiting intention is due to the cost of maintaining tourist customers much cheaper than attracting new visitors (Um et al., 2006). Revisit intention is considered as consequences of the satisfaction of tourists (Bigne and Shanchez, 2001). Customers who get satisfaction on the products or services they buy tend to make the repurchase of the product. Prior research suggests that a large push of tourists to return to a destination is due to past experiences such as the satisfaction of vacation, attractiveness, and perceived value (Petrick J.F, 2002; Um et al., 2006). While the two dimensions of tourists' attitudes in mediating the impact of revisit intention factors intention are (1) the desire to recommend to others, and (2) the desire to return to visit (Lin, 2012). Repeated behavioral intentions to a destination are the initial attitudes of loyalty behavior. Loyalty happens because the tourists get satisfaction, as a result of the fulfillment of their expectations in tourist attractions.

Riza et al. (2012) stated the physical environment of cities such as iconic buildings, tourist attractions as part of the attributes of city branding affect consumer attitudes forward. Conscious or not, the actions of tourists to come to a place influenced by their attitudes and beliefs. (Oppermann (1999) argued that understanding the attitude of tourists in terms of visiting is the foundation in developing marketing strategies and management of tourism, this is also a part of the development of motivation theory and decision making a journey. The previous research mentioned that tourists are willing to spend more if they feel the high quality of service and tend to make repeat visits if their expectations are met (Quintal and Polzynsky, 2010).

The Research Hypothesis. Based on this literature review, the hypothesis can be formulated as follows:

$\mathrm{H} 1$ : City branding has a significant effect on the satisfaction of tourists;

$\mathrm{H} 2$ : City branding has a significant effect on the revisit intention;

H3: Tourists' satisfaction has a significant effect on revisit intention.

\section{METHODS OF RESEARCH}

This research used explanatory research type with quantitative approach. The explanation to be studied in this research was associative that obtain a deep understanding of the relationship between variables and test the hypothesis for generalization purposes. The research location was Ambon city, located in eastern part of Indonesia. The reason was this city is in addition to the administrative center of Maluku province, and also the city had many natural attractions, marine and beach tourism, historical monuments, various national and international events and socio-cultural conditions of interest to be visited by tourists. Three variables studied were city branding, tourist satisfaction, and revisit intention. The sampling technique used non-probability sampling that was purposive sampling, in another word the determination of sample based on certain consideration, where the respondent is considered suitable with population characteristic that was domestic tourist 18 years old and above and understands about city branding of Ambon city. Respondent's profile includes respondent's gender, respondent's age, education, occupation, area of origin, a frequency of respondents visited Ambon city as well as a source of respondent information about Ambon 
city. Validity and reliability testing performed before the research instrument used, to collect data.

The Data Collection and Research Sample. As the survey research, the data used are both primary and secondary data obtained directly from the research respondents and other sources such as municipalities officials and related offices. Research respondents were 18 years old domestic tourists and over who were doing tourist visits in the city of Ambon. Data collection was done by filling questioner by respondent. The population type was the infinitive population, thus in the determination of the sample size used the formula from Lemeshow et al. (1997) so that the total sample was 142 people. The questionnaires are distributed as many as 200 , and 142 are defined which met the population criteria, consisting of $73.2 \%$ (104 male) and 26.8\% (38) female. The data collection activities started from October 2016 to January 2017.

The Research Instrument. The form of the questionnaire according to previous studies and used to collect information from respondents. The questionnaire contained fourteen indicators of the city branding variable, adapted from the Anholt research instrument (2007). Eight indicators of the variable of tourist satisfaction were adapted from Manhurun et al (2014). Three indicators of the revised intention were adapted from Ryu et al. (2008), Lin (2012). The measurement scale used in this research is Likert Scale with five choices; strongly agree (5), agree (4), neutral (3), disagree (2) and strongly disagree (1).

The Data analysis. Data analysis consisted of the use of 'Descriptive Statistics' which aimed to describe the frequency of respondents' answers, while' Inferential statistics' aimed to analyze how much influence of city branding application to tourist satisfaction, and revisit intention, and the influence of variable satisfaction on revisit intention. Analyzing descriptive statistics using frequency tables, whereas inferential statistics were analyzed by using Generalized Structured Component Analysis (GSCA) and other tools were SPSS for window version 20.

The Test of Validity and Reliability Instrument:

1) Validity test aimed to determine the accuracy and accuracy of instruments used in data collection. Analyze instrument used was the Product Moment correlation technique. The minimum requirement of the correlation coefficient (critical $r$ ) was 0.30 . If the result of $r$ was positive, and $r$ result $\geq 0.30$ then the item was valid (Now and Roger 2010). Thus the calculation results showed the correlation coefficient of all question items greater than 0.30 . This means that all question items were valid for use as a data collection tool.

2) The reliability test aimed to measure the extent to which instruments are trusted and consistent in collecting data. Testing using Cronbach Alpha technique where an instrument is said to be reliable if it had the alpha ( $\alpha$ ) of 0.6 or more (Arikunto, 2010). The calculation results as in Table 1, showed that all cronbach alpha values in the overall variables of this study were greater than 0.6 as in Table 1 below:

Table 1 - Reliability Test

\begin{tabular}{|c|c|c|c|}
\hline Variable & Coefficient Reliability & Cut Off & Description \\
\hline City Branding $(\mathrm{X})$ & 0.952 & 0.6 & Reliable \\
\hline Traveler's Satisfaction $\left(\mathrm{Y}_{1}\right)$ & 0.926 & 0.6 & Reliable \\
\hline Revisit Intention $\left(\mathrm{Y}_{2}\right)$ & 0.853 & 0.6 & Reliable \\
\hline
\end{tabular}

Source: Primary data processed 2017.

\section{RESULTS AND DISCUSSION}

The criteria of hypothesis testing stated that if the critical ratio $(\mathrm{CR})$ is an asterisk $\left({ }^{*}\right)$ or $\mathrm{CR} \geq \mathrm{t}$-table $(\mathrm{t}=2,00$, alpha $=0,05)$, the hypothesis is said to have a significant effect of the exogenous variable on the endogenous variable. Direct correlation test results are presented in Table 3.

This descriptive analysis is based on Table 2, which showed that the average score of respondents of city branding $(X)$ variable was 4.08 . This figure interprets that the variable of city branding is included in a very high category, besides indicating the respondent tend to 
perceive that city branding of Ambon city including very good. City taglines, historical and cultural relics and local wisdom contribute positive feedback to visitors. The attractiveness of the city as well as tourist services can also meet the desires and needs of tourist; especially the local transport service was quite good with the highest average score of 4.37. This finding also showed that the average score of respondents' answers to the variable satisfaction of tourists $(\mathrm{Y} 1)$ of 4.27 which means that the variable satisfaction of tourists including very high category. This indicates that respondents tend to perceive that the city branding aspect of Ambon city can contribute a very high level of satisfaction to the visitors. The attractiveness of the city, recreational facilities, resident friendliness, and urban security are indicators that contribute greatly to the variable of tourist satisfaction. In addition to these two variables, these findings also showed the average score of respondents' answers to the variable revisit intention (Y2) of 3.95, which can be interpreted as a number that was in the high category.

Table 2 - Distribution of Respondents' Perception

\begin{tabular}{|c|c|c|c|}
\hline Variable & Indicator & Average Score & Variable Score \\
\hline City Branding & $\begin{array}{l}\text { Hear the city of Ambon globally } \\
\text { City contribution in national history } \\
\text { City contribution in national culture } \\
\text { The attraction of the park \& building } \\
\text { Environmental hygiene } \\
\text { Local transport facilities } \\
\text { Educational facilities } \\
\text { Recreation facilities } \\
\text { The friendliness of the people } \\
\text { City security } \\
\text { Entertainment } \\
\text { Comfortable city suites } \\
\text { Work opportunities } \\
\text { Business opportunities }\end{array}$ & $\begin{array}{l}3.82 \\
4.23 \\
4.14 \\
3.59 \\
4.22 \\
4.37 \\
4.22 \\
4.18 \\
4.36 \\
4.34 \\
4.03 \\
4.25 \\
3.62 \\
3.78\end{array}$ & 4.08 \\
\hline Tourists' Satisfaction & $\begin{array}{l}\text { Satisfied with the appeal of the city } \\
\text { Satisfied with leisure facilities } \\
\text { Satisfied with the hospitality of the people } \\
\text { Satisfied with city security } \\
\text { Satisfied with educational facilities } \\
\text { Satisfied with public services } \\
\text { Satisfied with job opportunities } \\
\text { Satisfied with the city tagline }\end{array}$ & $\begin{array}{l}4.35 \\
4.99 \\
4.38 \\
4.35 \\
4.21 \\
4.18 \\
3.73 \\
3.96 \\
\end{array}$ & 4.27 \\
\hline Revisit Intention & $\begin{array}{l}\text { Ever visited } \\
\text { Intention to visit again } \\
\text { Intentions to recommend }\end{array}$ & $\begin{array}{l}3.68 \\
4.11 \\
4.07\end{array}$ & 3.95 \\
\hline
\end{tabular}

Source: Primary data, processed 2017.

Table 3 - Hypothesis Test Results

\begin{tabular}{|c|c|c|c|c|c|c|}
\hline Research Hypothesis & Exogenous & Endogenous & Coefficient Direct & SE & CR & Conclusion \\
\hline $\mathrm{H}_{1}$ & City Branding & Traveler Satisfaction & 0,422 & 0,083 & $5,10^{*}$ & Accepted \\
\hline $\mathrm{H}_{2}$ & City Branding & Revisit Intention & 0,459 & 0,117 & $3,91^{*}$ & Accepted \\
\hline $\mathrm{H}_{3}$ & Traveler Satisfaction & Revisit Intention & 0,347 & 0,139 & $2,49^{*}$ & Accepted \\
\hline
\end{tabular}

Source: Primary data, processed 2017.

Note: * Significant

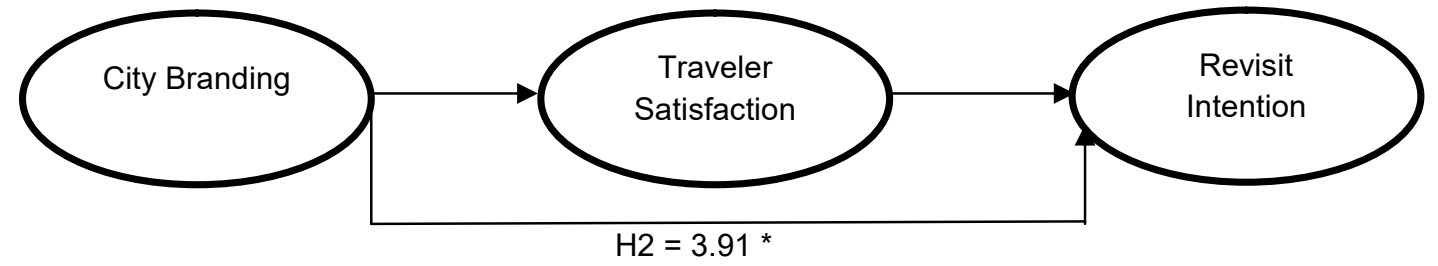

Figure 2 - Research Model 
This indicates that respondents tend to intend to return to the city of Ambon due to feelings of satisfaction over various facilities and services obtained. On the other side of the declaration of 'Ambon to the Music City of World' with various music events held, has an appeal to visitors. Likewise, historical relics, culture, and local wisdom contribute to visitors who wish to know more about the history and culture of Ambon city community. Thus, if referring to the level of customer satisfaction and responses of respondents to the variable revisit intention, it can be stated that the implementation of the concept of city branding in the city of Ambon by the city government is very effective and impact on the intention of return visits tourists. So, also as one of the marketing concept, city branding can be used as a measuring instrument for a sustainable urban market.

H1: City branding significant effect on the satisfaction of tourists.

GSCA analysis results (Table 3) obtained a direct coefficient of 0.422 and CR value of $5.10 *$. This means the value of $C R>t$-table $(t=2.00$, alpha $=0.05)$. This result means that city branding has a significant effect on the satisfaction of tourists at $95 \%$ confidence level. Thus, $\mathrm{H} 1$ is empirically proven and otherwise accepted. A direct positive coefficient value that is $0,422(42,2 \%)$ indicate that if there is a change in city branding variable, it will be followed by the change of $42,2 \%$ in a variable of tourist satisfaction. The implication of this research result confirms that city (Ajzen, 1991)branding of Ambon city as one of measurement instrument of urban tourism can give satisfaction to a visitor. The city's attractions, historical and cultural heritage, security, resident friendliness, recreational facilities as well as local transport services contribute to satisfaction. Characteristic of white sand beaches, with iconic buildings such as 'Jembatan Merah Putih' which lies in the middle of Ambon Bay, Siwalima Museum, Mangrove Forest and various cuisines, can give satisfaction so that tourists feel apart from all the boring routines. Satisfaction is the result of psychology that comes after getting the service (MacKay and Crompton, 1990). Previous studies have suggested that the attractiveness of cities affects the satisfaction of tourists (Pratminingsih et al., 2014). Customer satisfaction significantly affects future behavioral intentions (Reichheld and Sasser, 1990). City branding as one of the benchmarks of urban tourism development, becoming a proven city marketing strategy. Good management will have a direct impact on satisfaction, and satisfaction will build visitor loyalty thereby encouraging investment and increasing economic growth (Kavaratzis and Asworth, 2005).

H2: City branding has a significant effect on revisit intention.

GSCA calculation results (Table 3 ) obtained the value of the direct coefficient of 0.459 and $C R$ value of $3.91^{*}$. This means the value of $C R>t$-table $(t=2.00$, alpha $=0.05)$. Thus, it can be interpreted that the variable of city branding significantly influences the revisit intention at $95 \%$ confidence level. $\mathrm{H} 2$ was empirically proven and accepted in this study. A direct positive coefficient value was $0,459(45,9 \%)$ which means that if there was a change in city branding variable, it would be followed by $45.9 \%$ change in revisit intention variable. These results indicated that the intention of tourist visits to the city of Ambon was quite high. Implementation of city branding as a means of marketing communication, become the right instrument in influencing the tourists so there was planning to visit back to Ambon city. The tagline of 'Ambon city of music' and the 'Ambon Movement towards the Music City of the World' was still a power base to attract many people to come to visit. Organizing local and international-class music events was a public concern, often a special schedule for groups of visitors who have a musical talent. The Ambon city government's move was in line with Trueman et al. (2004) which stated that many tourists who visit a region because the area has a certain characteristic and a cultural heritage. Resources of ideas, capital, and local wisdom can be mobilized for sustainable city branding policies (Herget al., 2015). Previous findings had also proven that city branding significantly influences the revisit intention (Andriani, 2017).

H3 Satisfaction of tourists have a significant effect on revisit intention.

GSCA calculation results (Table 3 ) obtained the value of a direct coefficient of 0.347 and $C R$ value of $2.49{ }^{*}$. This means the value of $C R>t$-table $(t=2.00$, alpha $=0.05)$. Thus, it can be interpreted that the variable of satisfaction of tourists has a significant effect on the revisit intention at $95 \%$ confidence level. Therefore $\mathrm{H} 3$ is proven empirically and accepted in 
this research. A direct positive coefficient value was $0,347(34,7 \%)$ which means that if there was a change in the variable of tourist satisfaction, it will be followed by a change of $34,7 \%$ in revisit intention variable. These results indicate that the satisfaction of tourists that occur due to the impact of city branding can be a determinant of the revisit intention. In other words, the satisfaction of tourists could mediate city branding with a revisit intention. The customers satisfied would become pioneers or determinants in terms of continuity of a service business. Terms in determining the level of satisfaction are known from the attitude of fun, frequent visits, recommending friends and provide solutions to what was felt in the service tour. The Satisfied of customers would be loyal to the various services offered. The results of previous studies indicated a significant relationship between satisfaction and revisit intention (Ajzen, 1991, Chen and Phou, 2013, Khuong and Ha, 2014; Pratminingsi et al., 2014). In a very tight inter-regional tourism competition situation, many consumers choose to move to destinations.

\section{CONCLUSION}

This study aimed to direct the understanding of the impact of city branding implementation on the satisfaction of tourists and the intention of intention in the urban tourism industry in Ambon. The result of analysis of three variables indicates that the variable of city branding has a significant effect on the satisfaction of tourist. This showed that tourists are satisfied with the city branding attributes of Ambon city such as city attraction, recreational facilities, culture, community friendliness and various local wisdom available. City branding significantly influences the revisit intention. This showed that tourists use city branding as a consideration for the intention of visiting back to the city of Ambon. Tagline 'Ambon city of music' becomes one of the attractions force for tourists in planning a return visit to Ambon and there was a desire to recommend to others. This fact gave meaning that city branding was a predictor of satisfaction and revisit intention. The city branding was a strategy to strengthen the position of a city to be widely known. City branding can restore the identity of many unknown and neglected cities to compete globally. Acceleration of technology also changed the city from local to global environment and competition to become an attractive tourist destination. The variable of satisfaction of tourists had a significant effect on the revisit intention. This showed the feeling of satisfaction of tourists on the aspect of city branding influence on visiting return to Ambon. In other words, the satisfaction of tourists was able to mediate the city branding with a revisit intention. The customers satisfied would become pioneers or determinants in terms of continuity of a service business. Terms in determining the level of satisfaction are known from the attitude of fun, frequent visits, recommending friends and provide solutions to what is felt in the service tour. The Satisfied of customers will be loyal to the various services offered. Customer satisfaction factor is also an important element in adding customer value as well as value for tourism management companies. Tourist tendency to return to Ambon should get welcome from city government especially in developing tourism through city branding strategy. The intensity of promotion of 'Ambon city of music' through various music festivals, both national and world class. The city government could also synergize with tourism entrepreneurs in increasing the intensity of tourist visits. Another strategy was to develop a promotional program that describes the real condition of Ambon city, will greatly help the knowledge and awareness of tourists to this region. It is recommended that the city government of Ambon continue to develop city branding as one of the leading strategies for building the tourism sector. Periodical surveys to determine the level of satisfaction and expectations of tourists need to be done. Efforts to increase the number of tourists can be through cooperation with tour or travel agent, also through music events, sports, and culture. The establishment of tourism business groups and permits easy to obtain public business, which can help increase the number of tourist visits.

This research is still limited to the impact test of city branding implementation toward the satisfaction of tourists and the revisit intention. The research on the revision of intention is repeated so that the observation takes a long time. Thus, the longitudinal study approach 
was very precise in giving a complete conclusion. It is recommended that future research use other variables and different research methods to obtain more comprehensive results.

\section{REFERENCES}

1. Ajzen, 1991. The Theory of Planned Behavior; Organizational Behavior and Human Decision Processes, 50(2), pp.179-211.

2. Anholt, S. 2006. The Anholt City Brand Index: How the world views its cities, 2nd Editions.

3. Anholt, S. 2007. Competitive Identity: The New Brand Management for Nations, Cities, and regions, 1st Editions, Palgrave MacMillan UK.

4. Anwar and Sohail, 2004. Festival tourism in the United Arab Emirates: first-time versus repeat visitor perceptions, Journal of Vacation Marketing, 10(2), pp.161-170.

5. Arikunto, S. 2010. Prosedur Penelitian : Suatu Pendekatan Praktis, Rineka Cipta, Jakarta, pp. 52-58.

6. Aydin, S. and Ozer G. 2005. How switching costs affect subscriber loyalty in the Turkish mobile phone market: An exploratory study. Journal of Targeting Measurement and Analysis for Marketing, 14(2), pp.141-155.

7. Bigne J. E. and Sanchez, 2001. Tourism Image, Evaluation Variables, and after Purchase Behavior Inter-relationship, Journal of Tourism Management, 26, pp. 607-616.

8. Bigne J.E., Sanchez and L. Andreu, 2009. The Role of variety seeking in short and long run revisit intention in holiday destinations, International Journal of Culture, Tourism and Hospitality Research, 3(2) pp. 103-115.

9. Bitner, M.J., Faranda, W.T., Hubert, A.R., and Zeithaml, V.A, 1997. Customer Contributions and Roles in Service Delivery, International Journal of Service Industry Management, 8 (3), pp.193-205.

10. Chen, C.F and Chen, F.S. 2010. Experience quality,perceived value, satisfaction and behavioral intention for heritage tourist. Tourism Management, 31, pp. 29-35.

11. Chen, C. F and Phou S, 2013. A Closer Look At Destination: Image, Personality, Relationship and Loyalty, Elsevier: Journal Tourism Management, 36, pp. 269-278.

12. Herget J., Zdenka P., and Josef A., 2015. City branding and its economic impacts on tourism, Economics, and Sociology, 8(1), pp.119-126.

13. Kavaratzis, M, 2005. From city marketing to city branding: Towards a theoretical framework for developing city brands, place branding, Journal of Business, 1(1), pp. 5873.

14. Kavaratzis M. and Ashworth, 2004. City Branding: An effective assertion of identity or A transitory marketing Trick, Tijdschrift voor economic en social geografie Journal, 96(5), pp. 506-514.

15. Kemperman, Childers C.Y, and Williams K.H, 2003. Place Branding: Crating self-brand connections and brand advocacy, Journal of Product and Brand Management, 2(7), pp. 508-515.

16. Khuong, M. N., and Ha, H.T.T. 2014. The Influences of Push and Pull Factors on the International Leisure Tourists' Return Intention to Ho Chi Minh City, Vietnam - A Mediation Analysis of Destination Satisfaction, International Journal of Trade, Economic and Finance, 5(6), pp. 490-496.

17. Kusumawati, A. 2017. Integrating The Concepts of City Branding and Tourism Event on Behavioral Intention in Domestic Urban Tourism, RJOAS, 5(65),pp.154-161.

18. Lemeshow, S., Hosmer Jr. D.W., Klar J., Lwanga S.K. 1990. Adequacy of Sample Size in Health Studies, University of Massachusetts and World Health Organization, John Willey and Sons.

19. Leirissa R.Z., Pattykayhatu, J.A., Luhukay, H., Usman T, dan Meilissa S, 2004. Ambonku, doeloe, kini, esok, Pemerintah Kota Ambon Press, pp. 183- 192.

20. Lin, C. H. 2014. Effects of Cuisine Experience, psychological well being, and self-health perception on the revisit intention hot springs tourist. Journal of Hospitality and Tourism Research, 38(2) pp. 135-161. 
21. Mailanen, $T$ and Rainesto, 2009. How to Brand Nations, Cities, and Destination $A$ Planning Books for place Branding. Palgrave Mcmillan, USA.

22. Manhurrun, P. Ramseook., Seebaluck V.N and Naidoo P. 2015. Examining the structural relationships of destination image, perceived value, tourist satisfaction, and loyalty: case of Mauritius, Social and Behavioral Science, 175, pp. 252-259.

23. MacKay, K. And J. Crompton, 1990. Measuring the quality of recreation services, Journal of Park and Recreation Administration, 8(3), pp. 47-56.

24. Morgan N., Prltchard A. and Prlde R, 2004. Destination branding : Creating the unique destination proposition. Second Edition. Oxford: Butterworth-Heinemann.

25. Oppermann, M, 1999. Predicting destination choice - a discution of destination loyalty. Journal of Vacation Marketing, 5(1) pp. 51-65.

26. Payangan, Otto R, 2014. Pemasaran Jasa Pariwisata, IPB Press, Bogor, pp. 154-161.

27. Petrick, J.F. 2002. An examination of golf vacationers' novelty, Annals of Tourism Research, 29(2), pp.384 - 400.

28. Porpecsu, R. and Cobos, R. 2010. Strategic options in the construction of the bucharest brand through the aplication analysis of the measuring instruments for the urban brands. Annals of the University of Petrosany, Economics, 10 (1), pp. 154-161.

29. Pratminingsih, S. A., Christina L. R. and Tetty R. (2014). Roles of motivation and destination image in predicting tourist revisit intention: a case of Bandung, Indonesia, International Journal of Innovation, Management, and Technology, 5(1), pp. $19-24$.

Pujiastuti, E. E., Umar N., Suharyono and Kusumawati, A. 2017. Thre antecendents of behavioral intention regarding rural tourism destination, Asia Pasific Journal of Tourism Research, 22 (11), pp. 1169-1181.

30. Quintal, Vanessa and Polczynsky Aleksandra, 2010. Factor influencing tourist revisit intention, Asian Pacific Journal of Marketing and Logistics, 22(4), pp.554-578.

31. Reichheld, F and W.E Sasser, 1990. Zero defections: Quality comes to services, Harvard Business Review, 68, pp. 105-111.

32. Riza, Muge., Natciye Doratli and Mukaddes Fasli, 2012. City Branding and Identity, Social and Behavioral Sciences, 35, pp. 293-300.

33. Ryu, K ., Heesup H, and Tae H. K. 2008, The relationships among overall quick-casual restaurant image, perceived value, customer satisfaction, and behavioral intentions, International Journal of Hospitality Management, 27, pp. 459-469.

34. Sekaran, Uma, and Roger, Bougie, 2010. Research Methods for Business: A Skill Building Approach, Fifth Edition, UK: John Willey \& Sons.

35. Sjafrizal, 2014. Ekonomi Wilayah dan Perkotaan, Raja Grafindo Persada, Jakarta, pp. 183-190.

36. Trueman, M., Cornelius, $\mathrm{N}$ and Wallace, J. 2004. "Building brand value online, exploring relationships between company and city brands," European Journal of Marketing, 46(7), pp.1013-1031.

37. Um, S., Chon K., and Ro Y. 2006. Antecedents of revisit intention. Annals of Tourism Research, 33(4), pp. 1141-1158. 